\title{
Effects of Red Blood Cell Transfusions on Morbidity and Mortality in Non-Septic Critically III Patients; A Propensity Score Matched Study
}

\author{
Thomas Kander ( $\nabla$ thomas.kander@med.lu.se ) \\ Lunds universitet Medicinska fakulteten https://orcid.org/0000-0002-5404-2981
}

\section{Caroline Ulfsdotter Nilsson}

Lunds universitet Medicinska fakulteten

\section{Daniel Larsson}

Lunds universitet Medicinska fakulteten

\section{Peter Bentzer}

Lunds universitet Medicinska fakulteten

\section{Research}

Keywords: Red Blood Cell Transfusions, Critically III Patients, Adult patients

Posted Date: September 25th, 2020

DOI: https://doi.org/10.21203/rs.3.rs-81334/v1

License: () (1) This work is licensed under a Creative Commons Attribution 4.0 International License. Read Full License 


\section{Abstract}

\section{Background}

RBC-transfusions can be lifesaving, but are also associated with harm. To further examine any effect of red blood cell (RBC)transfusions given to critically ill patients that were not exposed to the risks of anemia or sepsis, we designed this retrospective propensity score matched study. The aim was to compare mortality and morbidity in non-septic critically ill patients that were given low-grade RBC-transfusions at hemoglobin level $>70 \mathrm{~g} / \mathrm{L}$ with patients without RBC-transfusions any of the first 5 days in intensive care.

Methods

Adult patients admitted to a general 9-bed intensive care unit between 2007-2018 at a tertiary university hospital, were eligible for inclusion. Patients that received $>2$ units RBC-transfusion during the first five days after admission, with pre-transfusion hemoglobin level $<70 \mathrm{~g} / \mathrm{L}$ or with severe sepsis or septic shock were excluded. Outcomes were 28-, 90- and 180-day mortality, highest acute kidney injury network (AKIN) score, days alive and free of organ support the first 28 days and highest sequential organ failure assessment score (SOFA-max).

Results

In total 9491 admissions were recorded during the study period. Propensity score matching at 1:1 ratio resulted in two well matched group with 682 unique patients in each. Median pre-transfusion hemoglobin was $98 \mathrm{~g} / \mathrm{L}$ (interquartile range 91-106 $\mathrm{g} / \mathrm{L}$ ). Mortality at the measured time points were higher in the RBC-group with an absolute risk increase for death at 180 days of $4.8 \%$ [95\% confidence interval 2.5 to $7.2 \%$ ], $(p<0.001)$. Low grade RBC-transfusion was also associated with renal, circulatory and respiratory failure as well as higher SOFA-max score.

\section{Conclusion}

Low-grade leukoreduced RBC-transfusions given to non-septic critically ill patients without significant anemia, was strongly associated with increased mortality, increased kidney-, circulatory- and respiratory- failure as well as with higher SOFA-max score. These findings further strengthen the evidence supporting a restrictive use of RBC-transfusions in critically ill patients.

\section{Introduction}

Anemia is common in critically ill patients and more than one fourth are transfused with allogenic red blood cell transfusions (RBC) [1,2]. RBC-transfusions can be lifesaving for many patients, but are also associated with harm such as transfusionassociated circulatory overload (TACO), transfusion-related immune modulation (TRIM), transfusion-related acute lung injury (TRALI) hemolytic reactions and infections [3]. However, also anemia is dangerous which makes risk-benefit assessment of RBC- transfusions important and necessary [4]. Many large randomized controlled trials (RCT) with high level of evidence demonstrate that a restrictive transfusion strategy (hemoglobin level $>70 \mathrm{~g} / \mathrm{L}$ ) is as safe as a liberal transfusion strategy (hemoglobin level > 90-100 g/L) [5-10]. In those RCTs, patients in both groups received RBC-transfusions and many patients may also have been exposed to the risk of anemia. Consequently, potentially adverse effects related to the low-grade RBCtransfusion itself, could be difficult to ascertain.

We have recently demonstrated that low grade RBC-transfusions given to septic patients were associated with increased mortality and morbidity in a liberal transfusion setting [11]. Given that RBC-transfusions may trigger TRIM, it is possible that harmful effects are more pronounced in septic patients than in other patient groups $[11,12]$. In an attempt to evaluate if the harmful effect of RBC transfusions in non-septic critically ill patients that were not exposed to the risks of anemia, we designed this retrospective propensity score matched study. The aim was to compare mortality and morbidity in critically ill patients without severe sepsis or septic shock that were given low-grade RBC-transfusions at hemoglobin level > $70 \mathrm{~g} / \mathrm{L}$ with 
controls without RBC-transfusions any of the first 5 days in intensive care. The hypothesis was that RBC-transfusions are harmful in non-septic critically ill patients without significant anemia.

\section{Methods}

\section{Data collection and study population}

The study was approved by Swedish Ethical Review Authority in Lund, Sweden (registration numbers 2014/916 and 2018/866) and the board waived the requirement for written informed consent. The manuscript was prepared according to the STROBE guidelines for observational studies [13].

All patients $\geq 18$ years of age, admitted to the 9-bed general intensive care unit (ICU) at Skåne University Hospital, Lund, Sweden between 2007 and 2018 were eligible for inclusion. For patients with multiple admissions to the ICU during the time of the study, only the first admission was included. To exclude patients with massive bleeding, patients who received high grade RBC-transfusion (defined as $>670 \mathrm{ml}$ or two units) any of the first five days in the ICU were excluded. All patients with severe sepsis or septic shock according to the Sepsis-2 definition [14] were excluded. RBC-transfusions were given at the discretion of the treating physician. To exclude patients exposed to the risks of anemia, all patients with a pre-transfusion hemoglobin level $<70 \mathrm{~g} / \mathrm{L}$ were excluded.

Mortality data was collected from the Swedish intensive care quality register PASIVA (Otimo Data AB, Kalmar, Sweden). Physiological and laboratory data and pre-existing conditions (age, gender, chronic obstructive pulmonary disease (COPD), renal failure, diabetes), outcome variables (except mortality) and fluid administration data were collected from raw data, i.e. from the electronic master chart system of the hospital (Melior, Cerner, N. Kansas City, MO, USA), or from the patient data management system at the ICU (Intellispace critical care and anaesthesia (ICCA), Philips, Amsterdam, the Netherlands).

\section{Outcome variables}

Mortality was assessed at 28, 90 and 180 days after ICU-admission and organ support was assessed by calculating days alive and free (DAF) of organ support for the first 28 days after admission to the ICU. For patients who died in the ICU, we counted the days without the specified organ support before death as previously described [15]. Organ support measures were vasopressors for circulatory failure, invasive mechanical ventilation for respiratory failure and renal replacement therapy (RRT) for renal failure. Renal failure was also evaluated according to the acute kidney injury network (AKIN) scoring system. The maximal AKIN score the first 10 days after ICU admission was used for analysis. To obtain an overall measure of organ failure we also used the maximum sequential organ failure assessment (SOFA) score during the first 28 days after admission.

\section{Statistics}

Patients receiving low grade RBC-transfusion ( $<670 \mathrm{~mL} /$ day) during the first 5 days of ICU admission were propensity score matched with non-transfused patients to adjust for differences in baseline variables associated with outcome. The propensity score was calculated with linear logistic regression using a one-to-many macro for SAS as previously described [16], with the covariates specified in Table 1. Physiological and laboratory variables used in the propensity score matching were collected within 90 min of admission to the ICU.

Sample size was based on the number of available patients during the study period. Variables were summarized using mean (standard deviation), median (interquartile range) or numbers (percentage). The propensity score matching was performed using SAS version 9.4 (SAS Institute Inc., Cary, NC, USA) prior to any comparison between the groups. Kaplan-Meier survival analysis was performed and is presented in graphs with corresponding stratified log-rank test. In accordance with previous recommendations comparisons between the groups after propensity score matching was performed with paired hypothesis testing [17]. The propensity score matching was performed by an independent statistician using SAS version 9.4 (SAS 
Institute Inc., Cary, NC, USA). Other analyses were performed with SPSS Statistics version 26 (SPSS Inc., Chicago, III., USA). A two-sided $P$ value of less than 0.05 was considered to indicate statistical significance.

\section{Results}

A consort diagram of all patients is presented in Figure 1. Out of 9491 patients 5240 patients remained after removing patients $<18$ years of age, multiple admissions, high-grade RBC-transfusion ( $>670 \mathrm{ml} /$ day), patients with pre-transfusion hemoglobin $<70 \mathrm{~g} / \mathrm{L}$ and patients with severe sepsis or septic shock. After propensity score match 682 patients were included in the RBC-group and 682 patients in the control group. The annual inclusion rate in both groups was similar (Additional file 1). Baseline demographics, comorbidity, and clinical, physiologic, and laboratory data in both groups are summarized in Table 1 and 2. After the propensity score match the standardized difference between groups for included baseline variables were reduced to $<10 \%$. For the baseline variables that were not included in the matching, differences between the groups were eliminated after the matching for all variables except for "Reason for admission, central nervous system" (Table 2).

All RBC-transfusions were leucoreduced. The median hemoglobin level before transfusion in the RBC-group was $98 \mathrm{~g} / \mathrm{L}$ (91$106 \mathrm{~g} / \mathrm{L})$. The median hemoglobin level on day 0 was 108 (104-111 g/L) for the RBC group and 109 (106-111 g/L) for the control group $(P=0.95)$. Daily median hemoglobin levels for the five first days for both groups are illustrated in Figure 2 . The median volumes of RBC-transfusion in the RBC- group the first five days after admission are shown in Figure 3.

\section{Outcomes}

Detailed results are presented in Table 3. Mortality at 28, 90 and 180 days were higher in the RBC-group (Table 3 and Figure 4). The absolute risk increase for death at 180 days for patients in the RBC-group was 4.8\% [95\% Cl: 2.5 to $7.2 \%$ ]; $(P<0.001)$. RRT and AKINmax demonstrated an increased risk for acute renal failure in the RBC group. Low grade RBC-transfusion was also associated with circulatory and respiratory failure as well as higher SOFA-max score.

\section{Fluids}

There was no difference either in the median daily administration of colloids, crystalloids or total fluid balance between the groups. The daily median total fluid administration and urinary output was larger in the RBC-group compared to the controls, Table 4.

\section{Discussion}

In this propensity score matched study, low-grade leukoreduced RBC-transfusions given to non-septic critically ill patients without significant anemia, was associated with increased mortality, increased kidney-, circulatory- and respiratory- failure as well as with higher SOFA-max score. This confirms the hypothesis that RBC-transfusions given to non-septic critically ill patients without significant anemia are harmful.

We collected data from 2007, prior to many high quality RCTs recommending a transfusion thresh-hold of $70 \mathrm{~g} / \mathrm{L}$. As recommended in the beginning of the study period, RBC-transfusions were often given in an ambition to increase oxygen delivery [18]. Hence, the vast majority of patients in the RBC group were transfused at a "safe" hemoglobin level without being exposed to the risks of anemia, indicated by a median pre-transfusion hemoglobin level of $98 \mathrm{~g} / \mathrm{L}$ (91-106). These data can therefore be used to evaluate the effect of RBC-transfusion itself on critically ill non-anemic, non-septic patients.

The propensity score-matching was performed to minimize the differences in baseline variables between the groups and to create the RBC- and the control-groups as similar as possible at ICU admission. Differences between the groups in variables not included in the matching, such as SAPS 3, disappeared after the matching with the exception of "Reason for admission, central nervous system", Table 2 . This further underline the validity of the propensity score-matching. 
Given that propensity score matching corrected for differences between the groups and that median hemoglobin level the first day of ICU admission did not differ between groups (Figure 2), the results in the present study imply that any adverse effects of the RBC-transfusion itself are responsible for the worse outcomes in the RBC group. This has previously been suggested in several reports, studies and guidelines [1,3,4,11,18-21]. In a retrospective registry study, similar to the present, Leal-Noval et al. included moderately anemic non-bleeding critically ill patients and matched patients that received RBCtransfusion with non-transfused patients [4]. Hospital mortality, ICU re-admissions, nosocomial infections and acute renal failure favored the non-transfused group. In contrast to the present study, pre-transfusion hemoglobin level was not reported and patients with nadir hemoglobin level $>95 \mathrm{~g} / \mathrm{L}$ were excluded from that study. As the patients in the present study were transfused at a higher hemoglobin level, thus not exposed for the risk of anemia and as the results showed an even stronger correlation between RBC-transfusion and bad outcome, this further strengthens the evidence that RBC-transfusions should not be given to non-anemic critically ill patients.

The reasons RBC-transfusions are harmful for non-anemic non-septic critically ill patients remain elusive, but as mentioned above known adverse effects of RBC-transfusion include TACO, TRALI and TRIM. Given that the total fluid balance between the groups did not differ (Table 4) TACO is a less likely explanation. Even if TRALI is the leading cause of direct transfusionrelated death, it is a rare event reported to occur in one case in 6000 to 600000 transfusions [22]. Also, TRALI is most common after plasma transfusion which makes this an unlikely cause of worse outcome after RBC-transfusion in the present study. RBC-transfusions contain many different immunomodulatory mediators that interact with and alter immune cell function in-vivo. The effect of these interactions may be both proinflammatory and immunosuppressive but are seldom obvious at the moment of the transfusion [23]. Nevertheless, these immunomodulatory properties of RBC-transfusions may be detrimental over time for critically ill septic and non-septic patients and may be responsible for the results in the present study[23].

The most obvious measure to avoid RBC-transfusions in critically ill would be to avoid anemia. As blood loss through diagnostic testing has been shown to be substantial and associated with RBC-transfusions it should be standard to minimize blood sampling and to use low-volume blood sampling tubes and in-line closed blood conservation devices on arterial lines for reinfusion of waste blood [24]. It would also be desirable to treat anemia without giving RBC-transfusion. A common type of anemia in critically ill patients is similar to the anemia described in chronic disease and the state of inflammation [1]. The pathophysiology of this anemia includes high levels of hepcidin leading to a state of functional iron deficiency [25] and a blunted response to erythropoietin [26]. Erythropoietin and iron supplementation have been studied in several RCTs but unfortunately without reduction in RBC-transfusions $[27,28]$. However, results of several ongoing trials on iron administration to critically ill patients are pending [21].

Finally, it is worth noting that our study has limitations and strengths. Limitations include that the study was retrospective and single center. Secondly baseline characteristics affecting outcomes were cautiously adjusted for, but it cannot be ruled out that undetected variables also were present. Strengths include that patients in neither group were exposed for the risk of anemia as patients with pre-transfusion hemoglobin level $<70 \mathrm{~g} / \mathrm{L}$ were excluded. This suggests that outcomes were less biased by any negative effect of anemia. Further, all physiological and laboratory variables and many pre-existing conditions were registered prospectively in electronic charts and collected as raw data directly from the electronic charts.

\section{Conclusion}

Low-grade leukoreduced RBC-transfusions given to non-septic critically ill patients without significant anemia correlated strongly with increased mortality, increased kidney-, circulatory- and respiratory- failure as well as with higher SOFA-max score. These findings further strengthen the evidence supporting a restrictive use of RBC-transfusions in critically ill patients.

\section{Abbreviations}

AKIN: Acute kidney injury network 
DAF: Days alive and free

ICU: Intensive care unit

RBC: Red blood cell

RCT: Randomized controlled trials

RRT: Renal replacement therapy

TACO: Transfusion-associated cardiac overload

TRALI: Transfusion related acute lung injury

TRIM: Transfusion-related immunomodulation

\section{Declarations}

\section{Ethics approval and consent to participate}

This study was approved by Swedish Ethical Review Authority in Lund, Sweden (registration numbers 2014/916 and 2018/866). All participants were offered an opt-out via advertisement in the local newspaper and the board waived the requirement for written informed consent.

\section{Consent for publication}

Not applicable.

\section{Availability of data and materials}

The datasets used and/or analyzed in the current study are available from the corresponding author on reasonable request.

\section{Competing interests}

The authors declare that they have no competing interests

\section{Funding}

Department funding only.

\section{Authors' contributions}

TK designed the study, built the database, wrote the first version of the manuscript and performed the statistical analyses after the propensity score match that was performed by a statistician. PB contributed to study design and did the first revision of the manuscript. All authors contributed to the interpretation of the data, revised the manuscript critically, and gave final approval of the version to be published.

\section{Acknowledgements}

We thank intensive care nurse Ann Svensson Gustafsson and computer technician Jan Karlsson for invaluable help with data extraction from the patient data management system.

\section{References}

1. Napolitano LM. Anemia and Red Blood Cell Transfusion: Advances in Critical Care. Crit Care Clin. 2017;33(2):345-64. 
2. Vincent JL, Jaschinski U, Wittebole X, Lefrant JY, Jakob SM, Almekhlafi GA et al. Worldwide audit of blood transfusion practice in critically ill patients. Crit Care. 2018;22(1):102.

3. Carson JL, Triulzi DJ, Ness PM. Indications for and Adverse Effects of Red-Cell Transfusion. N Engl J Med. 2017;377(13):1261-72.

4. Leal-Noval SR, Munoz-Gomez M, Jimenez-Sanchez M, Cayuela A, Leal-Romero M, Puppo-Moreno A et al. Red blood cell transfusion in non-bleeding critically ill patients with moderate anemia: is there a benefit? Intensive Care Med. 2013;39(3):445-53.

5. Holst LB, Haase N, Wetterslev J, Wernerman J, Guttormsen AB, Karlsson S et al. Lower versus higher hemoglobin threshold for transfusion in septic shock. N Engl J Med. 2014;371(15):1381-91.

6. Hajjar LA, Vincent J-L, Galas FR, Nakamura RE, Silva CM, Santos MH et al. Transfusion requirements after cardiac surgery: the TRACS randomized controlled trial. JAMA. 2010;304(14):1559-67.

7. Hébert PC, Wells G, Blajchman MA, Marshall J, Martin C, Pagliarello G et al. A multicenter, randomized, controlled clinical trial of transfusion requirements in critical care. Transfusion Requirements in Critical Care Investigators, Canadian Critical Care Trials Group. N Engl J Med. 1999;340(6):409-17.

8. Jairath V, Kahan BC, Gray A, Doré CJ, Mora A, James MW et al. Restrictive versus liberal blood transfusion for acute upper gastrointestinal bleeding (TRIGGER): a pragmatic, open-label, cluster randomised feasibility trial. The Lancet. 2015;386(9989):137-44.

9. Murphy GJ, Pike K, Rogers CA, Wordsworth S, Stokes EA, Angelini GD et al. Liberal or restrictive transfusion after cardiac surgery. N Engl J Med. 2015;372(11):997-1008.

10. Villanueva C, Colomo A, Bosch A, Concepcion M, Hernandez-Gea V, Aracil C et al. Transfusion strategies for acute upper gastrointestinal bleeding. N Engl J Med. 2013;368(1):11-21.

11. Nilsson CU, Bentzer P, Andersson LE, Björkman SA, Hanssson FP, Kander T. Mortality and morbidity of low-grade red blood cell transfusions in septic patients: a propensity score-matched observational study of a liberal transfusion strategy. Ann Intensive Care. 2020;10(1):1-10.

12. Carson JL, Terrin ML, Noveck H, Sanders DW, Chaitman BR, Rhoads GG et al. Liberal or restrictive transfusion in high-risk patients after hip surgery. N Engl J Med. 2011;365(26):2453-62.

13. Vandenbroucke JP, von Elm E, Altman DG, Gøtzsche PC, Mulrow CD, Pocock SJ et al. Strengthening the Reporting of Observational Studies in Epidemiology (STROBE): Explanation and elaboration. Int J Surg. 2014;12(12):1500-24.

14. Levy MM, Fink MP, Marshall JC, Abraham E, Angus D, Cook D et al. 2001 SCCM/ESICM/ACCP/ATS/SIS International Sepsis Definitions Conference. Intensive Care Med. 2003;29(4):530-8.

15. Russell JA, Lee T, Singer J, De Backer D, Annane D. Days alive and free as an alternative to a mortality outcome in pivotal vasopressor and septic shock trials. J Crit Care. 2018;47(333-7.

16. Bentzer P, Broman M, Kander T. Effect of dextran-70 on outcome in severe sepsis; a propensity-score matching study. Scand J Trauma Resusc Emerg Med. 2017;25(1):65.

17. Austin PC. Comparing paired vs non-paired statistical methods of analyses when making inferences about absolute risk reductions in propensity-score matched samples. Stat Med. 2011;30(11):1292-301.

18. Hebert PC, Tinmouth A, Corwin HL. Controversies in RBC transfusion in the critically ill. Chest. 2007;131(5):1583-90.

19. Vincent JL, Baron J-F, Reinhart K, Gattinoni L, Thijs L, Webb A et al. Anemia and blood transfusion in critically ill patients. JAMA. 2002;288(12):1499-507.

20. Carson JL, Stanworth SJ, Roubinian N, Fergusson DA, Triulzi D, Doree C et al. Transfusion thresholds and other strategies for guiding allogeneic red blood cell transfusion. Cochrane Database Syst Rev. 2016;10(CD002042.

21. Vlaar AP, Oczkowski S, de Bruin S, Wijnberge M, Antonelli M, Aubron C et al. Transfusion strategies in non-bleeding critically ill adults: a clinical practice guideline from the European Society of Intensive Care Medicine. Intensive Care Med. 2020;46(4):673-96. 
22. Silliman CC, Ambruso DR, Boshkov LK. Transfusion-related acute lung injury. Blood. 2005;105(6):2266-73.

23. Remy KE, Hall MW, Cholette J, Juffermans NP, Nicol K, Doctor A et al. Mechanisms of red blood cell transfusion-related immunomodulation. Transfusion. 2018;58(3):804-15.

24. Jackson Chornenki NL, James TE, Barty R, Liu Y, Rochwerg B, Heddle NM et al. Blood loss from laboratory testing, anemia, and red blood cell transfusion in the intensive care unit: a retrospective study. Transfusion. 2020;60(2):256-61.

25. Girelli D, Nemeth E, Swinkels DW. Hepcidin in the diagnosis of iron disorders. Blood. 2016;127(23):2809-13.

26. Hayden SJ, Albert TJ, Watkins TR, Swenson ER. Anemia in critical illness: insights into etiology, consequences, and management. Am J Respir Crit Care Med. 2012;185(10):1049-57.

27. Zarychanski R, Turgeon AF, McIntyre L, Fergusson DA. Erythropoietin-receptor agonists in critically ill patients: a metaanalysis of randomized controlled trials. CMAJ. 2007;177(7):725-34.

28. Shah A, Roy NB, McKechnie S, Doree C, Fisher SA, Stanworth SJ. Iron supplementation to treat anaemia in adult critical care patients: a systematic review and meta-analysis. Crit Care. 2016;20(1):306.

\section{Tables}

Table 1. Patient demographics before and after propensity matching 


\begin{tabular}{|c|c|c|c|c|c|c|c|c|}
\hline & \multicolumn{4}{|c|}{ Unmatched groups } & \multicolumn{4}{|c|}{ Propensity-matched groups } \\
\hline & & $\mathrm{RBC}[\mathrm{i}]$ & $\begin{array}{l}\text { Standardized } \\
\text { difference }\end{array}$ & $\begin{array}{l}\mathrm{P} \text { - } \\
\text { value }\end{array}$ & Control & RBC & $\begin{array}{l}\text { Standardized } \\
\text { difference }\end{array}$ & $\begin{array}{l}P \text { - } \\
\text { value }\end{array}$ \\
\hline & $\begin{array}{l}N= \\
3949\end{array}$ & $N=1291$ & & & $N=682$ & $N=682$ & & \\
\hline \multicolumn{9}{|l|}{ Pre-existing conditions } \\
\hline Age, mean (SD[ii]) & $58(19)$ & $64(16)$ & 0.315 & $<0.001$ & $63(17)$ & $63(16)$ & 0.022 & 0.686 \\
\hline Male gender, no (\%) & $\begin{array}{l}2342 \\
(59)\end{array}$ & $\begin{array}{l}745 \\
(58)\end{array}$ & 0.032 & 0.311 & $\begin{array}{l}405 \\
(59)\end{array}$ & $393(58)$ & 0.039 & 0.475 \\
\hline $\begin{array}{l}\text { Blood malignancy[iii], } \\
\text { no (\%) }\end{array}$ & $40(1.0)$ & $37(2.9)$ & 0.140 & $<0.001$ & $\begin{array}{l}13 \\
(1.8)\end{array}$ & $14(2.1)$ & 0.021 & 0.692 \\
\hline COPD [iv], no (\%) & $\begin{array}{l}340 \\
(8.6)\end{array}$ & $96(7.4)$ & 0.043 & 0.185 & $69(10)$ & $68(9.8)$ & 0.010 & 0.857 \\
\hline Cirrhosis, no (\%) & $40(1.0)$ & $25(1.9)$ & 0.076 & 0.010 & $\begin{array}{l}13 \\
(1.8)\end{array}$ & $13(1.8)$ & 0.000 & 1.000 \\
\hline $\begin{array}{l}\text { Immunosuppression[v], } \\
\text { no (\%) }\end{array}$ & 727 (18) & $74(5.7)$ & 0.107 & $<0.001$ & $\begin{array}{l}39 \\
(5.7)\end{array}$ & $35(5.1)$ & 0.026 & 0.633 \\
\hline Malignancy[vi], no (\%) & $525(13)$ & $\begin{array}{l}296 \\
(23)\end{array}$ & 0.250 & $<0.001$ & $\begin{array}{l}127 \\
(19)\end{array}$ & $\begin{array}{l}135 \\
(20)\end{array}$ & 0.037 & 0.492 \\
\hline $\begin{array}{l}\text { Nosocomial } \\
\text { infection[vii], no (\%) }\end{array}$ & $\begin{array}{l}138 \\
(3.5)\end{array}$ & $48(3.7)$ & 0.013 & 0.674 & $\begin{array}{l}28 \\
(4.1)\end{array}$ & $30(4.4)$ & 0.014 & 0.789 \\
\hline $\begin{array}{l}\text { Airway infection, no } \\
\text { (\%) }\end{array}$ & $494(12)$ & $\begin{array}{l}159 \\
(12)\end{array}$ & 0.005 & 0.874 & $82(12)$ & $84(12)$ & 0.004 & 0.934 \\
\hline Surgery[viii], no (\%) & $908(23)$ & $513(40)$ & 0.367 & $<0.001$ & $\begin{array}{l}230 \\
(34)\end{array}$ & $238(35)$ & 0.028 & 0.608 \\
\hline Gl[ix]-bleeding, no (\%) & $71(1.8)$ & $25(1.9)$ & 0.012 & 0.702 & $\begin{array}{l}15 \\
(2.1)\end{array}$ & $13(1.8)$ & 0.021 & 0.692 \\
\hline DIC [x], no (\%) & $103(2.6)$ & $25(1.9)$ & 0.467 & 0.161 & $\begin{array}{l}12 \\
(1.8)\end{array}$ & $13(1.9)$ & 0.011 & 0.840 \\
\hline $\begin{array}{l}\text { I.C. [xi] volume effect, } \\
\text { no (\%) }\end{array}$ & $\begin{array}{l}123 \\
(3.1)\end{array}$ & $38(2.9)$ & 0.011 & 0.723 & $\begin{array}{l}12 \\
(1.8)\end{array}$ & $16(2.3)$ & 0.041 & 0.445 \\
\hline \multicolumn{9}{|c|}{ Physiological and laboratory variables at admission[xii], mean (SD ) } \\
\hline Heart rate, mean (SD) & $92(23)$ & $94(24)$ & 0.113 & $<0.001$ & $93(24)$ & $94(24)$ & 0.025 & 0.645 \\
\hline SBP[xiii], (mmHg) & $126(30)$ & $\begin{array}{l}119 \\
(29)\end{array}$ & 0.234 & $<0.001$ & $\begin{array}{l}120 \\
(29)\end{array}$ & $\begin{array}{l}122 \\
(30)\end{array}$ & 0.054 & 0.316 \\
\hline Lactate (mmol/L) & $2.3(2.5)$ & $\begin{array}{l}2.4 \\
(2.3)\end{array}$ & 0.031 & 0.346 & $\begin{array}{l}2.5 \\
(2.6)\end{array}$ & $\begin{array}{l}2.5 \\
(2.4)\end{array}$ & 0.014 & 0.801 \\
\hline $\begin{array}{l}\text { Norepinephrine } \\
\text { ( } \mu \mathrm{g} / \mathrm{min})\end{array}$ & $\begin{array}{l}0.91 \\
(3.2)\end{array}$ & $\begin{array}{l}1.8 \\
(5.0)\end{array}$ & 0.205 & $<0.001$ & $\begin{array}{l}1.6 \\
(4.3)\end{array}$ & $\begin{array}{l}1.8 \\
(5.4)\end{array}$ & 0.038 & 0.479 \\
\hline Temperature ( ${ }^{\circ}$ Celcius) & $\begin{array}{l}36.6 \\
(1.2)\end{array}$ & $\begin{array}{l}36.7 \\
(1.4)\end{array}$ & 0.058 & 0.061 & $\begin{array}{l}36.6 \\
(1.4)\end{array}$ & $\begin{array}{l}36.7 \\
(1.5)\end{array}$ & 0.038 & 0.489 \\
\hline $\mathrm{PaO}_{2} / \mathrm{FiO}_{2}(\mathrm{kPa})$ & $33(18)$ & $32(20)$ & 0.014 & 0.672 & $33(18)$ & $33(22)$ & 0.038 & 0.488 \\
\hline Leucocytes (x 109/L) & $14(10)$ & $13(8.1)$ & 0.036 & 0.291 & $14(15)$ & $14(7.9)$ & 0.009 & 0.867 \\
\hline Platelets (x 109/L) & $225(97)$ & $\begin{array}{l}210 \\
(110)\end{array}$ & 0.140 & $<0.001$ & $\begin{array}{l}217 \\
(104)\end{array}$ & $\begin{array}{l}218 \\
(118)\end{array}$ & 0.010 & 0.850 \\
\hline
\end{tabular}




\begin{tabular}{|c|c|c|c|c|c|c|c|c|}
\hline $\mathrm{pH}$ & $\begin{array}{l}7.34 \\
(0.12)\end{array}$ & $\begin{array}{l}7.35 \\
(0.11)\end{array}$ & 0.139 & $<0.001$ & $\begin{array}{l}7.34 \\
(0.12)\end{array}$ & $\begin{array}{l}7.34 \\
(0.11)\end{array}$ & 0.024 & 0.651 \\
\hline Bilirubin ( $\mu \mathrm{mol} / \mathrm{L})$ & 12 (19) & $17(30)$ & 0.179 & $<0.001$ & $14(28)$ & $14(16)$ & 0.003 & 0.961 \\
\hline Creatinine ( $\mu \mathrm{mol} / \mathrm{L})$ & $\begin{array}{l}104 \\
(110)\end{array}$ & $\begin{array}{l}125 \\
(150)\end{array}$ & 0.152 & $<0.001$ & $\begin{array}{l}117 \\
(129)\end{array}$ & $\begin{array}{l}118 \\
(148)\end{array}$ & 0.003 & 0.949 \\
\hline PT/INR[xiv] & $\begin{array}{l}1.3 \\
(0.65)\end{array}$ & $\begin{array}{l}1.4( \\
0.72)\end{array}$ & 0.141 & $<0.001$ & $\begin{array}{l}1.4 \\
(0.73)\end{array}$ & $\begin{array}{l}1.4 \\
(0.68)\end{array}$ & 0.006 & 0.909 \\
\hline APTT[xv] (sec) & $35(17)$ & 39 (19) & 0.227 & $<0.001$ & $38(12)$ & $39(20)$ & 0.021 & 0.694 \\
\hline $\mathrm{Hb}[\mathrm{xvi}]$ & $122(18)$ & $\begin{array}{l}105 \\
(15)\end{array}$ & 1.037 & $<0.001$ & $\begin{array}{l}109 \\
(14)\end{array}$ & $\begin{array}{l}109 \\
(14)\end{array}$ & 0.016 & 0.766 \\
\hline
\end{tabular}

[a] Low grade red blood cell transfusion defined as $<670 \mathrm{ml}$ any of the first 5 days

[b] Standard deviation

[c] Lymphoma, acute leukaemia or myeloma

[d] Chronic obstructive pulmonary disease

[e] Chronic steroid treatment correlative to $\geq 0.3 \mathrm{mg} / \mathrm{kg}$ prednisolone/day, radiation, or chemo therapy

[f] Cancer spread beyond the regional lymph nodes

[g] Infection that developed after $\geq 48$ hours in hospital or secondary to surgical or medical procedure

[h] Before admission to intensive care

[i] Gastro-intestinal

[j] Disseminated intravascular coagulopathy

[k] Intra-cranial

[l] First value within 90 min after admission except for "Norepinephrine" which is the mean dose the first 12 hours

[m] Systolic blood pressure

[n] Prothrombin time

[o] Activated partial thromboplastin time

[p] Median hemoglobin level day 0 
Table 2. Unmatched baseline characteristics

Unmatched groups

Controls,
$n=3949$

$54(43-66)$

73)
$62(51-$

\section{Propensity-matched groups}

$\begin{array}{lllll}\text { RBC[i], } & \text { P-value[ii] } & \text { Controls, } & \text { RBC, } & \text { P-value[iii] } \\ \mathrm{n}=1291 & & \mathrm{n}=682 & \mathrm{n}=682 & \end{array}$

$60(47-69)$

$60(50-\quad$ N.S.

71)

\section{Reasons for admission[vi], $\mathrm{n}$}

(\%)

$\begin{array}{llllllll}\text { Trauma } & 272(6.9) & 122(9.5) & 0.003 & 35(5.1) & 43(6.3) & \text { N.S. } \\ \text { CNS[vii] } & 1334(31) & 431(25) & <0.001 & 192(28) & 227(33) & 0.02 & \\ \text { Hematologic } & 109(2.5) & 128(7.5) & <0.001 & 19(2.8) & 23(3.4) & \text { N.S. } \\ \text { Gastric } & 333(7.7) & 323(19) & <0.001 & 68(10) & 72(11) & \text { N.S. } \\ \text { Metabolic } & 505(12) & 211(12) & \text { N.S. } & 66(10) & 64(9.4) & \text { N.S. } \\ \text { Respiratory } & 1531(35) & 692(40) & <0.001 & 292(43) & 272(40) & \text { N.S. } \\ \text { Cardiovascular } & 952(22) & 660(39) & <0.001 & 188(26) & 199(29) & \text { N.S. } \\ \text { Hepatic } & 151(3.5) & 113(6.6) & 0.02 & 34(5.0) & 31(4.6) & \text { N.S. } \\ \text { Renal } & 393(9.1) & 316(18) & <0.001 & 62(9.1) & 78(11) & \text { N.S. } \\ \text { Other } & 347(8.0) & 136(7.9) & \text { N.S. } & 46(6.7) & 53(7.8) & \text { N.S. }\end{array}$

\section{Arrival route $\mathrm{n}(\%)$}

\begin{tabular}{|c|c|c|c|c|c|c|}
\hline Emergency department & $1885(44)$ & $\begin{array}{l}371 \\
(22)\end{array}$ & $<0.001$ & $187(27)$ & $\begin{array}{l}186 \\
(27)\end{array}$ & N.S. \\
\hline General ward & $1106(26)$ & $\begin{array}{l}603 \\
(35)\end{array}$ & $<0.001$ & $196(29)$ & $\begin{array}{l}186 \\
(27)\end{array}$ & N.S. \\
\hline Intermediate care & $56(1.3)$ & $38(2.2)$ & 0.02 & $15(2.2)$ & $\begin{array}{l}12 \\
(1.8)\end{array}$ & N.S. \\
\hline Operation & $564(13)$ & $\begin{array}{l}341 \\
(20)\end{array}$ & $<0.001$ & $124(18)$ & $\begin{array}{l}135 \\
(20)\end{array}$ & N.S. \\
\hline Other ICU & $440(10.2)$ & $\begin{array}{l}231 \\
(13)\end{array}$ & 0.02 & $115(17)$ & $\begin{array}{l}102 \\
(15)\end{array}$ & N.S. \\
\hline Postoperative care unit & $576(13)$ & $\begin{array}{l}349 \\
(8.1)\end{array}$ & 0.01 & $125(18)$ & $\begin{array}{l}158 \\
(23)\end{array}$ & 0.03 \\
\hline Other & $237(6.0)$ & $90(7.0)$ & N.S. & $44(6.5)$ & $\begin{array}{l}38 \\
(5.6)\end{array}$ & N.S. \\
\hline
\end{tabular}

[a] Red blood cell transfusion

[b] Mann-Whitney-U or Chi-2-test

[c] Wilcoxon rang sum or McNemars' test 
[d] Simplified acute physiology score 3

[e] Interquartile range

[f] Patients may have more than one reason for admission

[g] Central nervous system

\section{Table 3. Main outcome variables}

\begin{tabular}{|c|c|c|c|c|c|c|c|}
\hline \multirow[b]{2}{*}{ Outcome } & \multicolumn{2}{|c|}{$\begin{array}{l}\text { Propensity-matched } \\
\text { groups }\end{array}$} & \multicolumn{2}{|c|}{$\begin{array}{l}\text { Relative risk (95\% } \\
\text { CI[i]) }\end{array}$} & \multicolumn{2}{|c|}{$\begin{array}{l}\text { Absolute risk increase }(95 \% \\
\mathrm{Cl})\end{array}$} & \multirow[t]{3}{*}{$P[i i]$} \\
\hline & Control & RBC[iii] & & & & & \\
\hline & $\mathrm{n}=682$ & $n=682$ & & & & & \\
\hline 28-day mortality & $146(21)$ & \multicolumn{2}{|c|}{$188(28)$} & \multicolumn{2}{|c|}{1.29 (1.07 to 1.55$)$} & $\begin{array}{l}6.2 \%(1.6 \text { to } \\
11 \%)\end{array}$ & 0.01 \\
\hline 90-day mortality & $188(28)$ & \multicolumn{2}{|c|}{$231(34)$} & \multicolumn{2}{|c|}{1.23 (1.05 to 1.44$)$} & $\begin{array}{l}6.3 \%(1.4 \text { to } \\
11 \%)\end{array}$ & 0.01 \\
\hline 180-day mortality & $211(31$ & \multicolumn{2}{|c|}{$269(39)$} & \multicolumn{2}{|c|}{1.27 (1.10 to 1.47$)$} & $\begin{array}{l}8.5 \% \text { (3.5 to } \\
14 \%)\end{array}$ & 0.001 \\
\hline RRT[iv] & $19(2.8$ & \multicolumn{2}{|c|}{$52(7.6)$} & \multicolumn{2}{|c|}{2.74 (1.64 to 4.58$)$} & $\begin{array}{l}4.8 \%(2.5 \text { to } \\
7.2 \%)\end{array}$ & $<0.001$ \\
\hline AKIN[v] & $0(0-0)$ & \multicolumn{2}{|c|}{$0(0-1)$} & & & & $<0.001$ \\
\hline DAF of vasopressors & $28(25-28)$ & \multicolumn{3}{|c|}{$26(14-28)$} & & & $<0.001$ \\
\hline $\begin{array}{l}\text { DAF of mechanical } \\
\text { ventilation }\end{array}$ & $27(23-28)$ & \multicolumn{3}{|c|}{$25(9-27)$} & & & $<0.001$ \\
\hline SOFA max[vi] & $6(4-9)$ & \multicolumn{3}{|c|}{$8(5-10))$} & & & $<0.001$ \\
\hline
\end{tabular}

Data are presented as number (\%) or median (interquartile range)

[a] Confidence interval

[b] Wilcoxon rang sum or McNemar's test

[c] Low grade red blood cell transfusion defined as $<670 \mathrm{ml}$ any of the first 5 days

[d] Renal Replacement Therapy

[e] AKIN max the first 10 days after admission

[f] Maxiumum Sequential Organ Failure Assesment score the first 10 days after admission

\section{Table 4. Fluid therapy, first 5 day}




\begin{tabular}{|c|c|c|c|c|c|}
\hline \multicolumn{6}{|c|}{ Propensity score matched groups } \\
\hline \multirow[t]{2}{*}{ Fluids per day[i] } & \multicolumn{2}{|c|}{ Control, n=737 } & \multicolumn{2}{|c|}{ RBC[ii], n=737 } & \multirow[t]{2}{*}{ P[iii] } \\
\hline & Median & IQR[iv] & Median & IQR & \\
\hline Colloids[v] (ml) & 170 & 0 to 530 & 291 & 130 to 655 & n.s. \\
\hline Crystalloids[vi] (ml) & 1100 & 270 to 2500 & 1100 & 890 to 3600 & n.s. \\
\hline Fluids in, total[vii] (ml) & 3000 & 1700 to 4500 & 3400 & 2800 to 5000 & $<0.001$ \\
\hline Urine output (ml) & 1800 & 790 to 2700 & 2100 & 920 to 2900 & 0.04 \\
\hline Total fluid balance[viii] (ml) & 340 & -30 to 1900 & 710 & -90 to 1700 & n.s. \\
\hline RBC-transfusion (ml) & 0 & 0 to 0 & 300 & 120 to 410 & $<0.001$ \\
\hline
\end{tabular}

Table 4. Volumes are presented with 2 value figures.

[a] For patients with ICU-stay $<5$ days the mean per day was calculated for the length of stay

[b] Low grade red blood cell transfusion defined as $<670 \mathrm{ml}$ ( $<2$ units) any of the first 5 days

[c] Wilcoxon rang sum test

[d] Interquartile range

[e] Defined as albumin $(200 \mathrm{mg} / \mathrm{ml})$, albumin $(5 \mathrm{mg} / \mathrm{ml})$, dextran $70(60 \mathrm{mg} / \mathrm{ml})$ and hydroxyethyl starch $(200 / 0.5$ and $130 / 0.4)$

[f] Crystalloids represents the sum of $\mathrm{NaCl} 9 \mathrm{mg} / \mathrm{ml}$ and Ringer's Acetate

[g] Fluids in, total represents the sum of all enteral and parenteral administered fluids but not RBC-transfusions [h] Insensible perspiration and RBC-transfusions not included

\section{Figures}




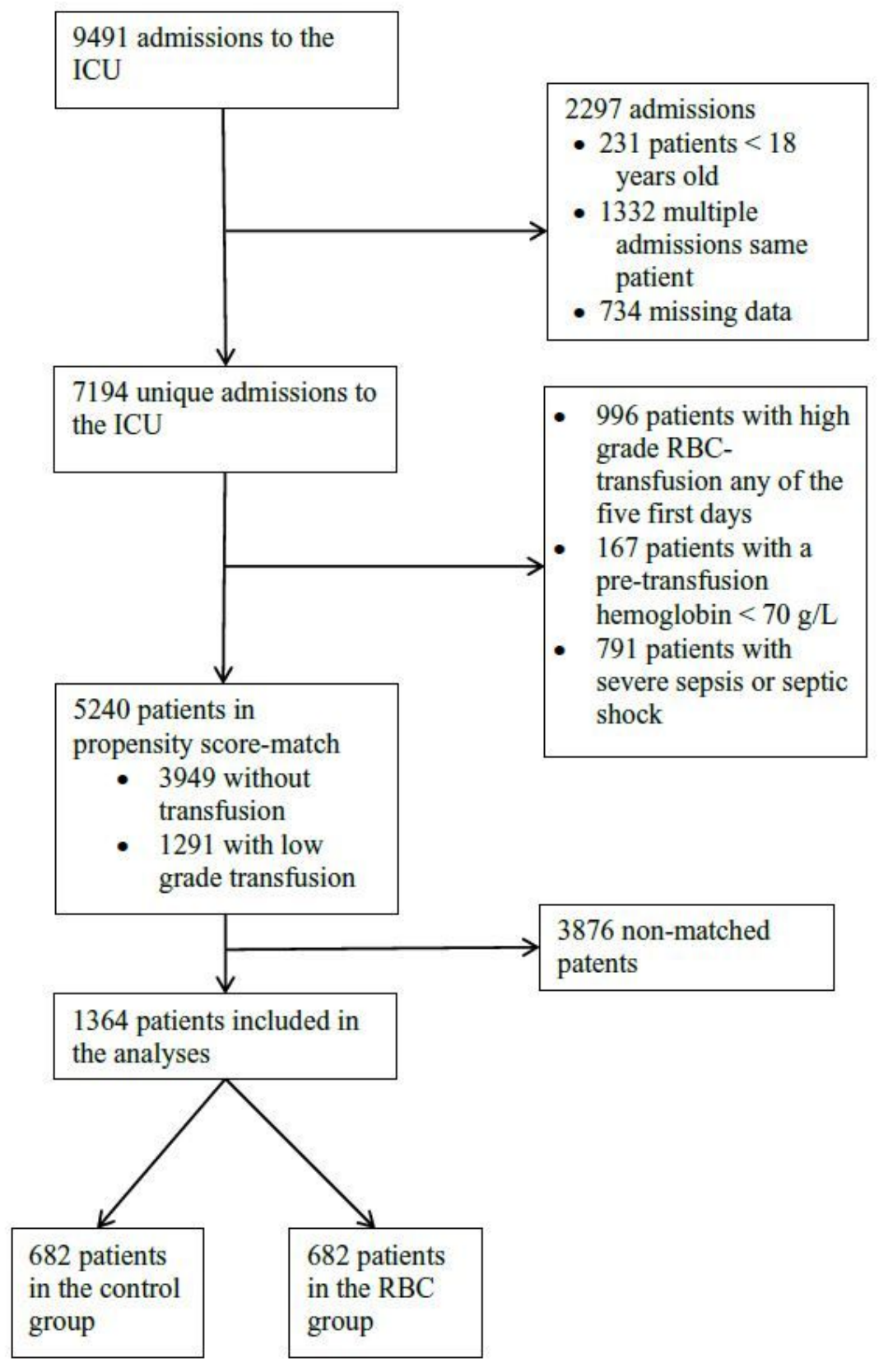

\section{Figure 1}

Consort diagram 


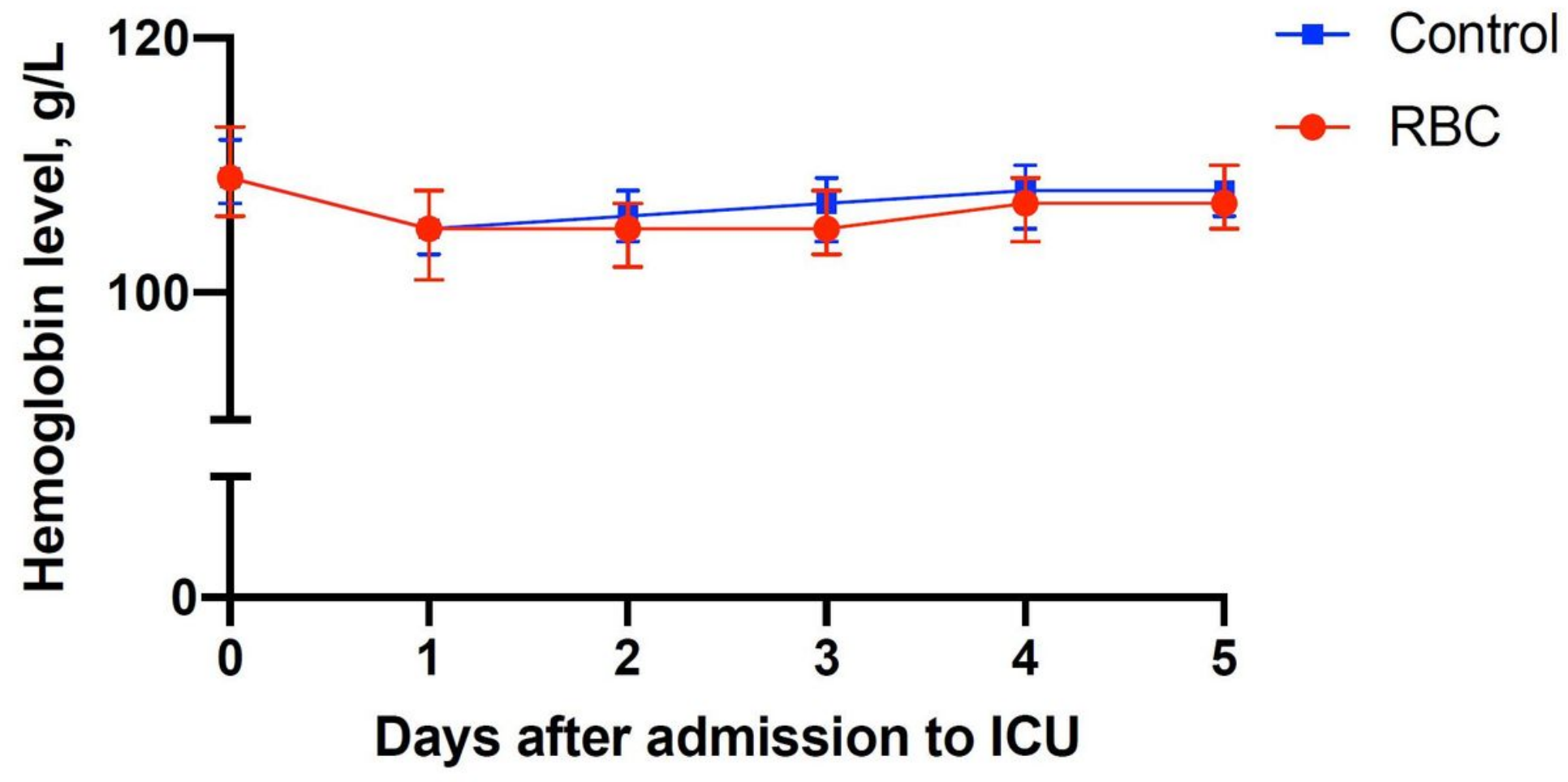

Figure 2

Median hemoglobin level with interquartile range. $\mathrm{RBC}=$ group with patients who received red blood cell transfusion any of the first five days. 


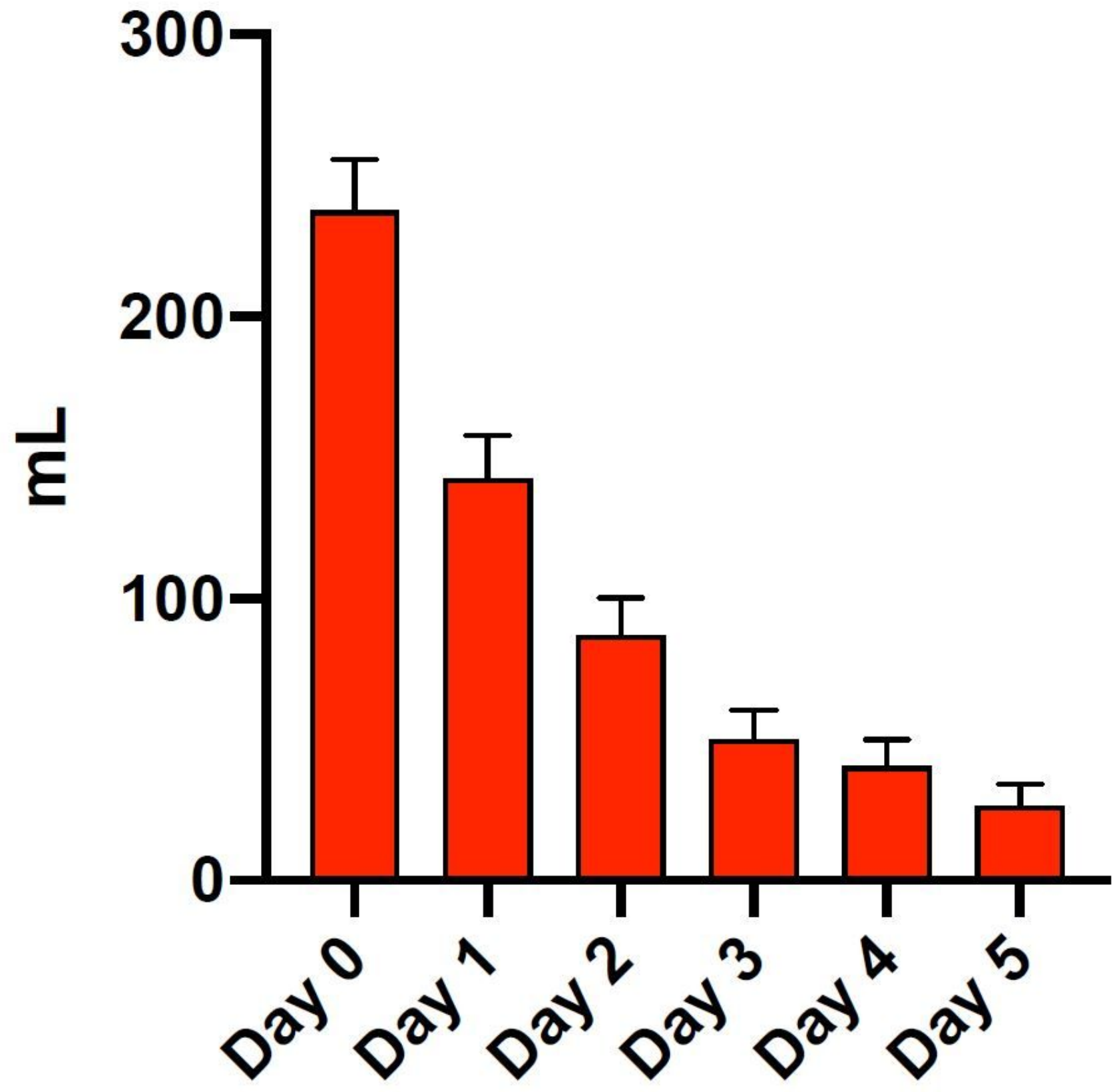

Figure 3

Mean red blood cell transfusion per day with 95\% confidence interval in the RBC-group. RBC= group. 


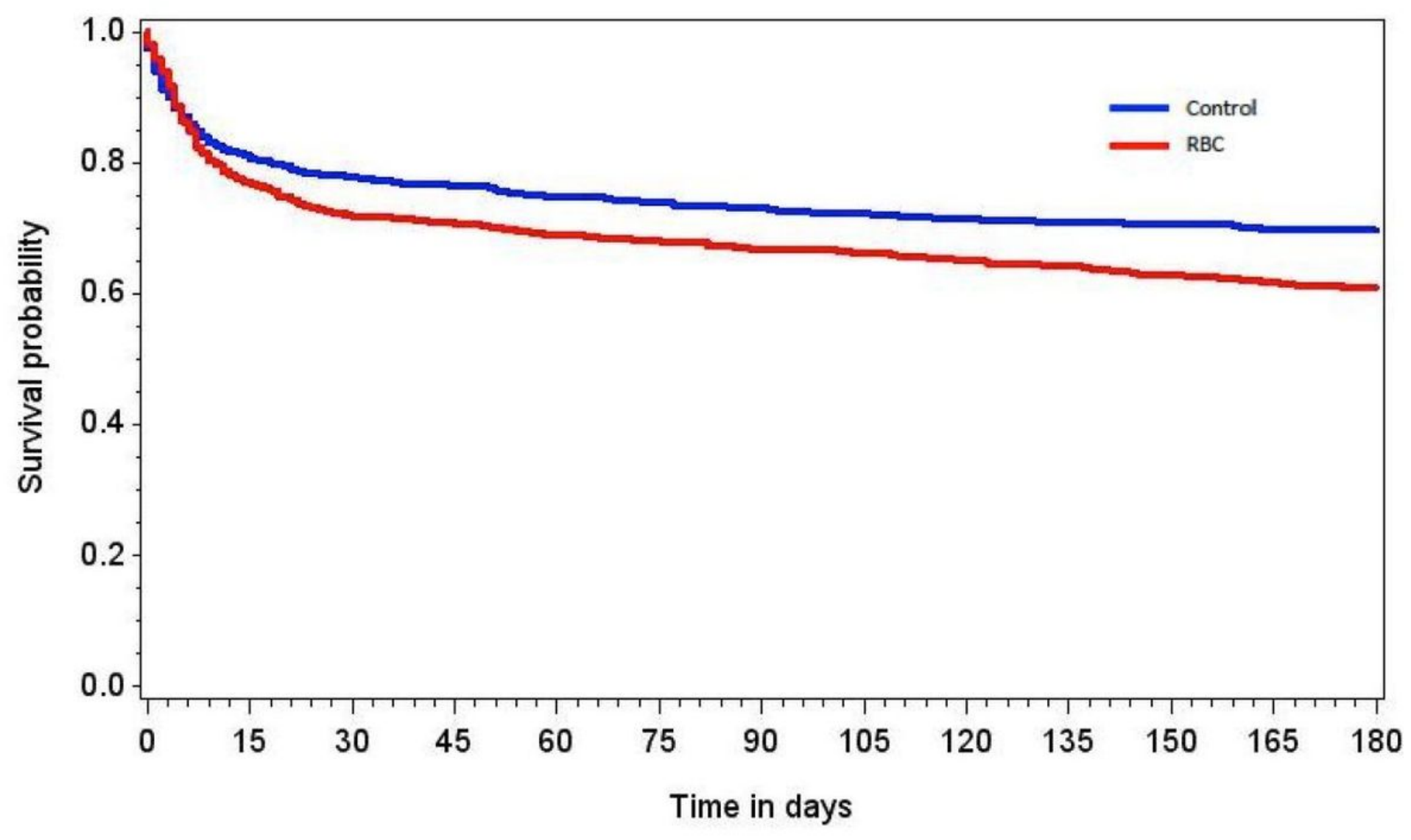

Figure 4

Kaplan-Meier curves of 180-day survival in the control group (blue line) and the RBC group (red line) $(P<0.001$, stratified logrank test). $\mathrm{RBC}=$ group with patients who received red blood cell transfusion any of the first five days. 